\title{
Value Chain Analysis of Chilgoza Pine Nut at Southeastern Region of Afghanistan
}

\author{
Noorullah Rahmani, Hedayatullah Salari, and Abdulrashid Wiar
}

\section{ABSTRACT}

\begin{abstract}
Chilgoza pine forests offer a significant source of income for owners especially for smallholder farmers in southeastern Afghanistan. In 2019/2020 season, on the basis of kernel, from total global production of the pine nuts (17220 MT), only 9\% (1500 MT) was produced in Afghanistan. Southeastern region of the country (Paktia, Paktika and Khost provinces) is a known and rich region of the pine nut where roughly $86 \%(37,785$ hectare) of total forest lands exist and approximately 120600 families take directly advantage from Chilgoza products with 250-360 million US dollars income per year. Therefore, this study was conducted at southeastern region of Afghanistan during 2019-2020 to investigate the entire value chain of chilgoza pine, analyze production capacities and identify main producers and traders. This study was based on interviews, questionnaires, direct observation, and literature reviews. Analysis of community level surveys revealed if the current unsustainable value chain practices not altered will result in continued decline of existing chilgoza forest stands, will lags significantly behind its major global competitors in international market and will lose chilgoza (Black Gold) concept opportunity. The findings of the current study revealed that for better handling of chilgoza pine nut, the forest regeneration and entire value chain program will be effective resolution. Establishing modern chilgoza pine nut processing factories in remote areas needed to be balanced with road conditions, water and electricity are vital requisite and urgent need.
\end{abstract}

Keywords: chilgoza, marketing, pine nut, tribal ownership.
Submitted : July 10, 2021

Published : August 06, 2021

ISSN: $2684-1827$

DOI: 10.24018 /ejfood.2021.3.4.340

Noorullah Rahmani*

Department of Horticulture, Paktia University, Paktia, Afghanistan. (e-mail: nrahmani@pu.edu.af)

Hedayatullah Salari

Department of Horticulture, Paktia

University, Paktia, Afghanistan.

(e-mail: h.salari786@ gmail.com)

Abdulrashid Wiar

Department of Forestry and Natural Resources, Paktia University, Paktia, Afghanistan.

(e-mail: abdulrashid.wiar@gmail.com)

*Corresponding Author

\section{INTRODUCTION}

Chilgoza pine is the most valuable, important ecological and economic social forestry species of Afghanistan. It is confined to dry temperate forest of the HindukushHimalayan region, which includes eastern and southeastern Afghanistan. In eastern Afghanistan (Kunar, Nuristan, Laghman, Kapisa and Nangarhar), Chilgoza pine is distributed between 2100-3350 masl [1] and in southeastern part (Paktia, Khost and Paktika), it is found between 1800 2300 masl [12]. Pine nuts are the main non-timber forest product yielded from these trees. Chilgoza pine plays an important role in socio-economic development of rural communities living nearby chilgoza forests [3], [23]. The pine forest not only provides pine nuts as an economic commodity, but also provides fuel wood, medicinal plants, pasture, and shelter for livestock as well as wildlife habitat and other environmental services.

Three species of pine kernel (P. gerardiana, P. koraiensis and $\mathrm{P}$. pinea) are traded internationally and have been part of global trade for many years. Among them, Pinus gerardiana (chilgoza), which is the main species of Afghanistan's forests, is the important and leading pine nut in international market. In recent years, the market growth for pine nut trading has been observed and particularly in the United States becoming a 100 million US dollars [10].
This trend might be explained by a recent Irish study, which gave evidence that nut consumption can help in decreasing the risk of coronary heart disease (CHD) and sudden cardiac arrest [10]. The edible nuts are highly nutritious; contain healthy amounts of essential minerals, having high antioxidant content, carminative, stimulant, and expectorant properties. Its kernels are rich source of fats, proteins, and carbohydrates with no cholesterol like other edible pine nuts [19].

Data are not available on world production of pine nuts [6]. The species are quite difficult to distinguish morphologically from one another. World pine nut production was estimated at 39,950 MT (kernel basis), this was $86 \%$ higher than in 2004 . The increase was due to the expansion of China's production capacity, which had grown 10 times since 2004. Indeed, China was the principal producer in 2014. The crop yielded 25,000 MT (62\% of total production share). North Korea came next (5000 MT or $12 \%$ share), followed by Afghanistan (3100 MT or $8 \%$ share) and Pakistan (3000 MT or 7\% share). Russian Federation contributed 2500 MT (6\% share) to the world market [7].

Pine nuts exports from Afghanistan are estimated to approximately US\$ 70 million yearly, which is predominantly exported in shell. Afghanistan produces 27,000 to 35,000 metric tons of pine nuts and are traded through the porous border illegally and sold at a lower price 
due to lack of processing, packaging, and marketing facilities in Afghanistan [4]. A system needs to be built to facilitate the pine nuts farmers and a platform need to be provides to address their issues. The emerging scenario requires renewed impetus and excellent value chain strategies to overseas market opportunities.

A value chain perception involves the addition of value as the products develop from input suppliers to farmers and consumers. Value adding results from various activities comprises of bulking and cleaning, grading, packaging, and fetching, storing as well as processing [17]. Moreover, value chain analysis focuses on demand of market, quality standards, domestic, regional, and national, dynamics of markets and define constrains and opportunities for the performers of the chain (Kaplinsky and Morris 2001).

Chilgoza value chain has not been comprehensively studied in Afghanistan. There is insufficient of information in several aspects of entire value chain. Thus, realizing the importance of Chilgoza value chain, it was deemed necessary to study entire value chain practices at Southeastern Afghanistan in order to sustainably manage this valuable natural resource.

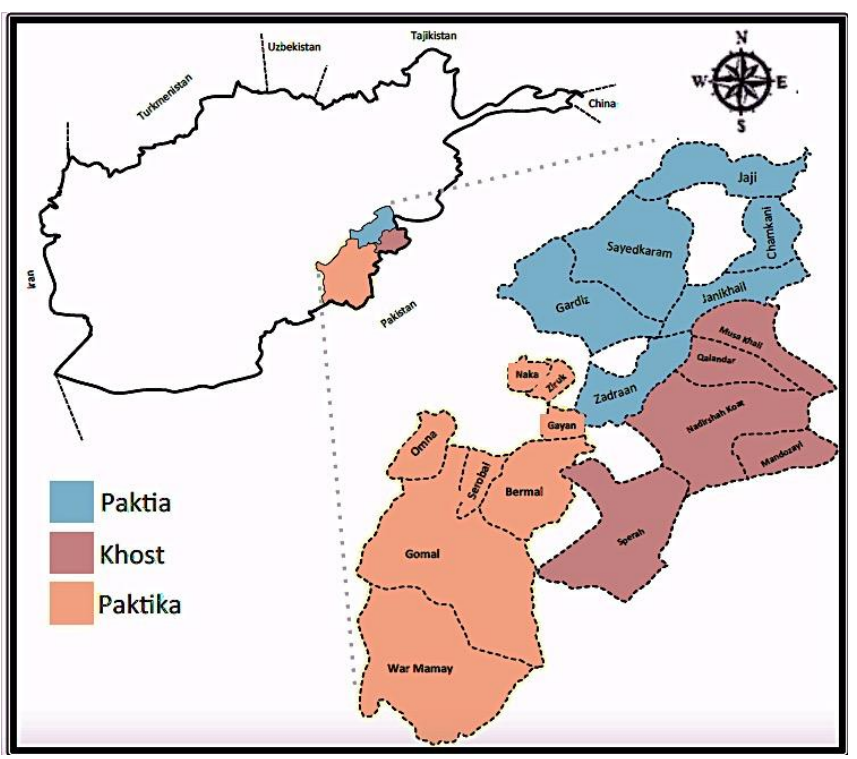

Fig 1. Study area location map.

\section{Methodology}

The study covered southeastern region (Paktia, Paktika and Khost provinces) of Afghanistan, which covers roughly $86 \%$ of total pine nut forests. This study was based on interviews, questionnaires, and direct observations. For interviews, face to face and telephone interviews methods applied. The questionnaire was created and developed separately for three categories i.e., (Community members/villagers inside the Chilgoza forest range, Governmental and non-governmental organization involve in Chilgoza pine management and traders involve in trading of Chilgoza pine nut). A cross-sectional design of the study was adopted for the value chain analysis of chilgoza pine nut to achieve the required data from the selected respondents at a time. The data collected in three stages. In first phase, Paktia and selected districts and accordingly Paktika and Khost covered in second and third phases. Districts were selected based on the majority forest area.
Initial aim was fixed to interview at least 2-6 subjects in each district. In practice, a total of 69 subjects living around chilgoza pine forests within 17 districts were interviewed (Fig.1). A total of 11 participants from government and non-government organizations included representatives from provincial Industry and Commerce office, ACCI, PAIL and DAIL offices involve in Chilgoza pine management, and 13 traders involve in trading of Chilgoza pine nut were also interviewed. Data were analyzed through descriptive and inferential statistics.

\section{RESUlTS AND DISCUSSION}

Results deduced from the present investigation as well as relevant discussion have been summarized under the following heads:

\section{A. Distribution of Chilgoza at District Scale}

Nearly, all districts of Paktia and Paktika provinces have Chilgoza forest, while in Khost, it's found in some specific districts of Musakhil, Spera, Qalander, Dwa Mande and Nadersha Koat. The major production province is Paktia (Jaji-Aryoub, Zadran, Ahmadkhil, Chamkani, Janikhil, Sayedkaram and Gardiz districts) and Paktika (Wormamay, Gomal, Bermel, Zerok, Sarobi, Gayan, Omna and Naka districts).

\section{B. Chilgoza Forest Ownership}

Based on Afghanistan's Forest Law, natural forests are government property and communities are allowed to use this resource under a community based natural resource management approach. However, according to our findings, local villagers believe that the forest are their own property and is divided among tribes, communities or villages living near to forest zone. Based on the surveyed results, the majority $(83 \%)$ of chilgoza forests are owned and handled by tribe/village living near to forest area, while a small percentage $(17 \%)$ are owned by individual families (Fig. 2). Individual family ownership is more common only in some area in the districts of Omna and Gomal of Paktika and Musakhil and Qalander of Khost provinces. The results are in accordance with [11], [16].

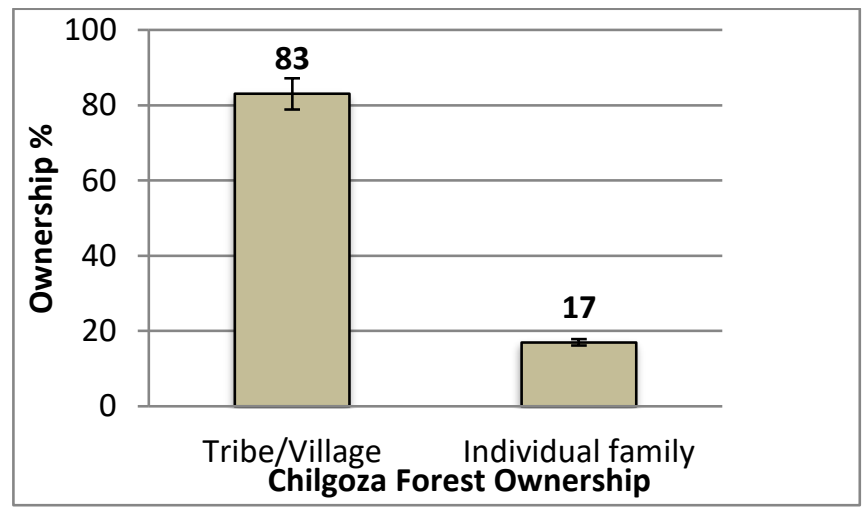

Fig. 2. Chilgoza Forest Ownership in Paktia, Paktika and Khost.

\section{Mapping the Chilgoza Pine Nut Value Chain}

The chilgoza pine nut market composed of domestic consumption and exportation of the raw in-shell chilgoza pine nuts. Based on the data, about $15-30 \%$ of produced 
pine nuts have domestic consumption and the rest portion (70-85\%) is exported to foreign countries. Also, some amount of the pine nut kept by growers for either their own household consumption or other market channels. The higher percentage of the exportation shows higher international market needs. Hence growers and governmental agencies should take strategies to organize the informal sector and diagnose other chilgoza pine nut destinations.

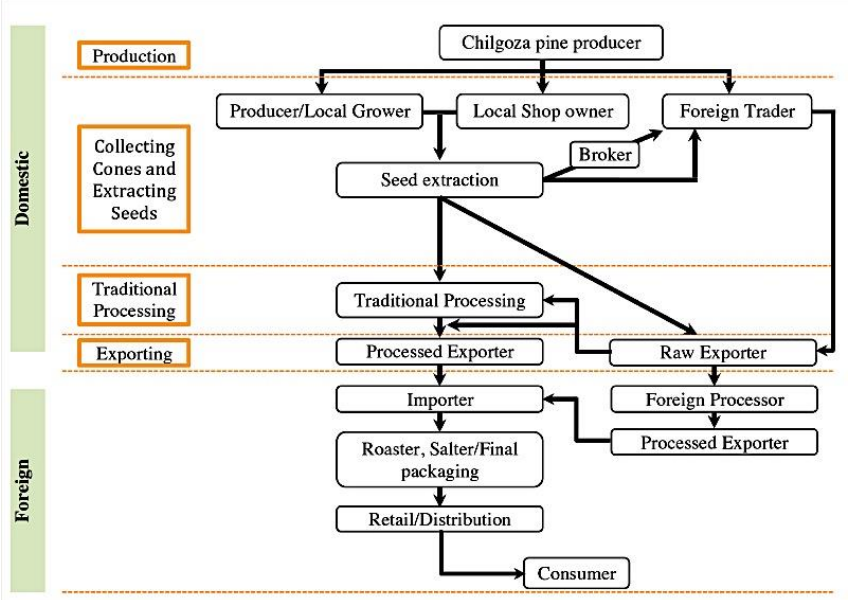

Fig 3. Chilgoza pine nut value chain in Afghanistan.

As displayed in Fig. 3, different stakeholders are involved in the chilgoza pine nut value chain. At a national level the structure of the market is characterized by a large number of chilgoza forest owners. From the buyer's side the structure involves numerous retailers, traders, agents, and processors. There are few barriers to entry or exit into this market.

The initial stage of the barter begins when producers/growers sell raw pine nuts locally to traders, processors, retailers, brokers, and the informal sector. In this case, most of the chilgoza farmers, located in remote areas, are not organized in organized groups, and very often do not have access to market prices. So asymmetric information is observed, because buyers are better informed and have more power in terms of negotiation than growers. Additionally, the lack of price differentiation between the size of the raw material (cones/seeds) and quality during the barter is another main constraint.

In the second stage, chilgoza pine nuts are collected to be exported or processed by local industry or the informal sector. Local governance, donors and other agencies have greatly supported this type of industry. It should be highlighted that Afghanistan exports mostly partially processed pine nuts and exported in bulk mainly to China, Pakistan, India, and Central Asian markets. Labor seasonality, lack of capacity building and business management are the main issues of the domestic industry. Hence improving local processing practices, innovations in sizing and packaging, providing management assistance and contemporary technology, are the essential needs to be prepared. Furthermore, establishment of processing factories in the remote areas needed to be balanced with road conditions, water, and electricity.

At a global scale, 9\% of chilgoza pine kernels (15000 MT) exported to China and Central Asian Markets while partial processed nuts are shipped mainly to Pakistan and India (International Nuts and Dried Fruits Council, 2019/2020). Therefore, in addition to partial processing in the country, it substantially appears that some value addition takes place in foreign courtiers, which include roasting, packaging, and labeling. This issue reveals that the minor portion of the consumer price is generated in Afghanistan, while the major price and income is generated in the foreign countries. Thus, Afghan chilgoza growers receive much lower revenues from this produce.

\section{Cone harvesting and collection:}

Trees are usually gown on mountain (steep rocky slope) areas. They commence their initial yield at least 20-years to be elapsed from planting. At this time the trees are adequately taller with abundant fragile limbs. Cone collection is done either by forest owners or by contractors. So, the steep slopes and careless collection by contractors from one hand and the taller trees and fragile limbs on the other hand, made cone collection as a difficult practice. Harvesters use metal hook like tools attached to long spindle-wooden sticks for cone collection (Fig.4 a \& b). Such tools though can harvest the cones, but they may damage the meristematic tissues or break the limbs subsequently affects seasonal growth and inherent growth habit. As the tree age increases, harvesting process become more troublesome. Chilgoza pine collection starts at the end of August and early September and continues for two months. Similarly, findings were also observed by [11], [15], [16].

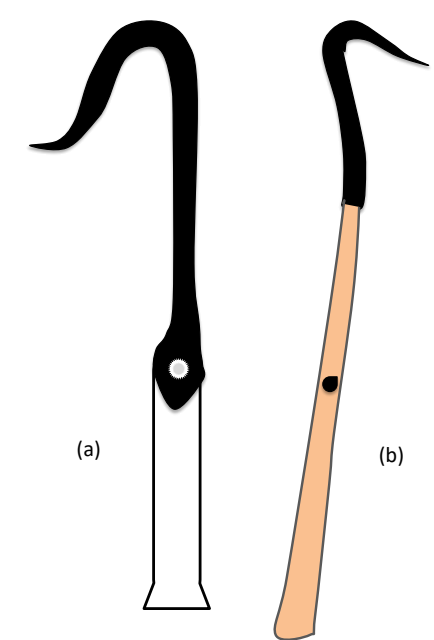

Fig. 4. a) Sharp iron metal hook; and b) Hook attached with long stick.

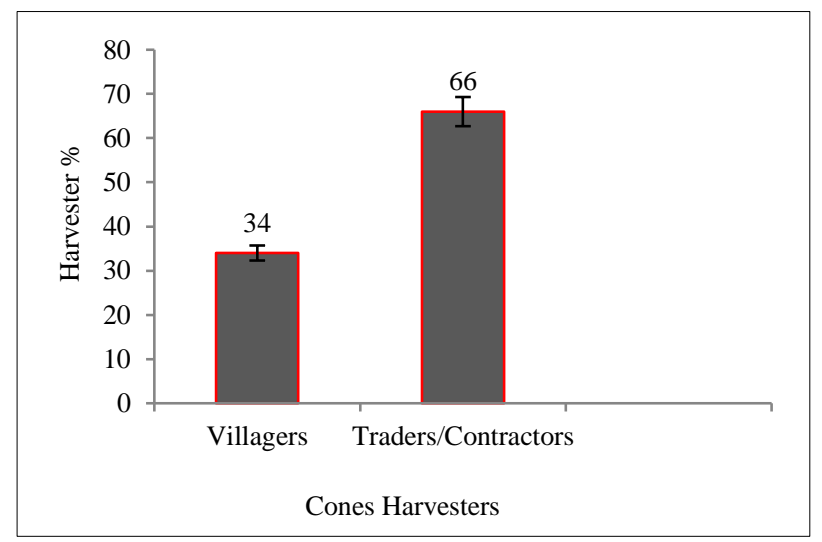

Fig. 5. Chilgoza Pine cones harvesters. 
The data presented in Fig. 5 indicate that majority of the communities $(66 \%)$ contract their chilgoza forests to local and outside contractors. The contract system is common in larger size forests, while in small size forests; local villagers directly harvest chilgoza pine cones. Generally, harvested cones sell by contractors/traders while sometimes; villagers process the cones (drying and nut extraction) and sell the cleaned pine nut to the domestic market. In the contract system, chilgoza forest stands are given to the contractors for a short period of time during the harvest season. These contractors bring their own workers and equipment and harvest the cones while in majority area, villager use to work as workers to minimize damage to the tree. Larger forest area, lack of proper harvesting and processing tools, insufficient processing places and technical workers are the main hindrances that communities obliged to lease out their forests to contractors. Tribal Council (Shura), which is leading by tribal leaders, are responsible for deciding and contracting out chilgoza forests to contractors. Local harvester service is limited to the domestic or regional market while the contractor role in the market linkage is to the national and international market level, hence is the major difference between contractors and local harvesters in the market linkage. These findings are in agreement with the findings of [11], [15], [16], [21], ]25].

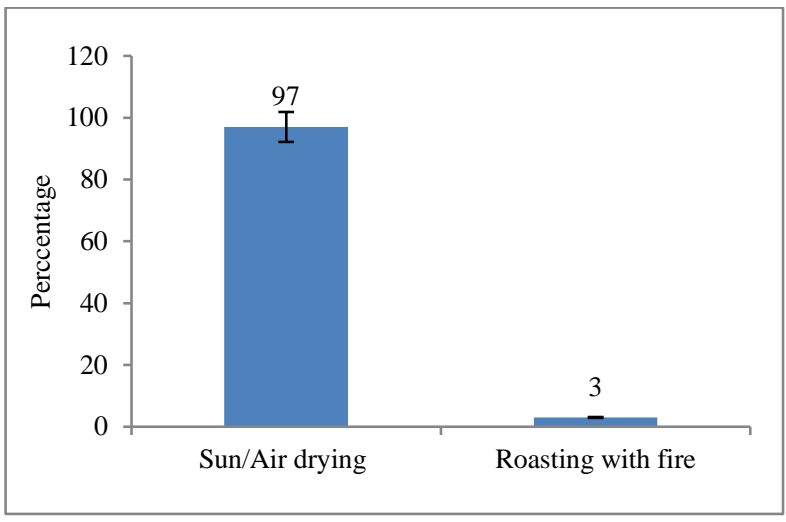

(a)

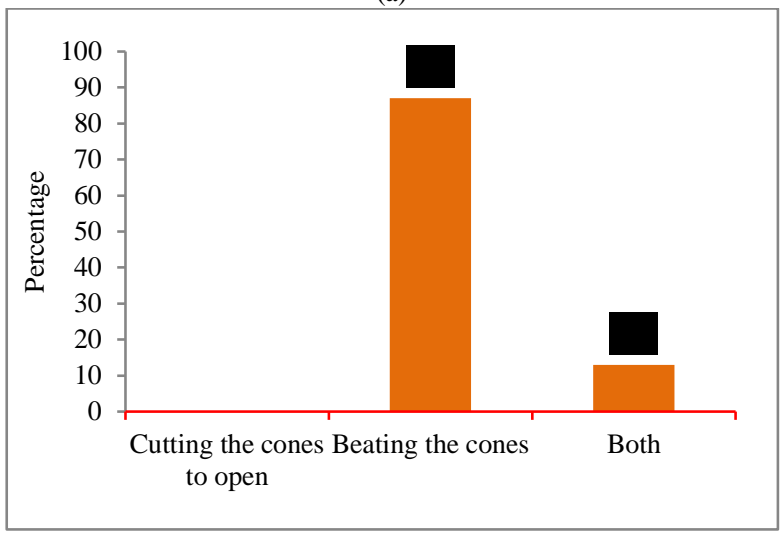

(b)

Fig. 6. a) Methods of cones drying and b) nut extraction method

\section{Drying and Nut Extraction}

Base on the study findings as indicating in Fig. 6, sun/air drying is the most common method of cone drying in Afghanistan; however, use of fire or coals to aid in drying has been reported. In some areas, cones are piled on rooftops or ground to dry naturally in the sun. In some areas, in order to speed up the drying process, the cones cover with dry grass/fodder. Alternatively, some people store the cones inside a room and then expose them to the sun for drying. The drying process is completed between 15-30 days by spreading the cones on dried ground exposed to air and sunlight. This drying process is slow and inefficient and depends on the climatic situation. Beating of cone with stick or over a hard surface is common method of nut extraction in Afghanistan. The cones of pine nut is placing in a sack and beating with a stick or over a hard surface (Fig. 4 b). During the extraction process, some seeds are damaged and wasted by striking and beating. Cones that do not open their scales after the drying process are cut open with shears or clippers. These results are in accordance with [11], [13], [16], [21], [22], [26].

\section{E. Packaging, Marketing, and Trading}

According to the study findings, communities sell their produce to the local traders/contractors and also directly to the domestic market without nut drying and roasting. Some proportion of the nuts is stored for social obligations. Pine nuts are generally sold to different buyers/traders every year. The produce is packing in large jute or burlap sacks and transported to the market or main collection point. The findings are in agreement with the findings of Kuhn et al. [11] and Shalizi and Khuram, [16]. Surveyed results revealed that the contractors/traders collect chilgoza with cones from forest, cleaned the nuts and transfer them in shelled form to Khost (Chilgoza Market) which is known as the main collection point. After, they transported them to the Kabul wholesales market and Chilgoza processing factory where chilgoza nut is processed and packaged with international standard level and then export abroad mainly to China. In retail and domestic market, pine nuts are roasting and selling to consumers. Roasting is done manually using gas or wood as heating source. One kilogram of chilgoza pine can be roasted by $(0.75 \$)$ and an average $(200 \mathrm{~g})$ is reduced after roasting.

Chilgoza pine nuts were traded illegally and sold at a lower price as there were no processing, packaging, and marketing facilities in Afghanistan. Fortunately, effort made in processing and marketing by Afghan government to process chilgoza pine in Afghanistan and export through proper legal channels. Air corridor facility made by Afghan government to export chilgoza pine nut to China. According to the agreement, twenty tons of chilgoza nuts will be exported to China through Kabul-Shanghai air corridor daily [8]. Amid the rapid increase of pine nuts exports through the air corridor to China, an Afghan investor has invested $\$ 5$ million in a pine nuts processing factory in Kabul. The factory has the ability to process and package at least 8-12 tons of pine nuts a day in line with international norms [9]. Still, the factory processing capacity (3600 tons/year) is at lower level as compare to the chilgoza production (27000-35000 tons/year) level, thus the capacity should be expanded, and the numbers of processing units need to be increased. This attempt has altered the illegally traded rout and in majority, the Afghan Chilgoza is exporting by Afghan brand name to the world. Earlier, due to the substandard processing, Chilgoza pine nut was traded through the porous border illegally to Pakistan, where the 
nuts were cleaned and/or de-shelled with machinery and then sold at higher prices by their name.

Price per kilogram of unshelled pine nuts as revealed by this study varies among provinces ranging from a low of 10 USD reported in Paktika to a high of 23.75 USD in Khost province (Table I). Total mean price paid per kilogram of unshelled pine nuts across the provinces was 17.5 USD. The quality (size, taste, level of damage incurred during processing) of pine nuts differs among provinces and high quality pine nuts are sold for better prices than low quality ones. The price also influenced by easy availability and accessibility of the products. The average price per kilogram of pine nuts in 2006 was reported as \$2.87 USD by Kuhn et al. [11], $\$ 8.51$ USD by Shalizi and Khuram [16] and compared with the higher average price (\$ 40 USD) roasting pine nut in 2019 revealed by this study. Since price per kilogram of unshelled pine nuts is known to vary from year to year and is also dependent on supply and demand factors, thus this should not be construed as evidence of trending. In Kabul markets, one kilogram of roasting unshelled pine nuts was priced at \$15 USD in 2015 and 2016, \$ 18 in 2017 and \$ 40 USD in 2019.

TABLE I: MEAN, Minimum AND MAXIMUM PRICE (USD) AND STANDARD ERROR (S.E.) OF ONE KILOGRAM UNSHELLED PINE NUTS SOLD BY LOCAL VILLAGERS TO LOCAL TRADERS AND TO LOCAL MARKET

\begin{tabular}{cccccc}
\hline \hline Provinces & Mean & Min & Max & S.E. & N \\
\hline Paktia & 18.38 & 10.00 & 23.13 & 0.52 & 35 \\
Paktika & 16.49 & 10.00 & 21.25 & 0.74 & 19 \\
Khost & 17.65 & 12.50 & 23.75 & 0.88 & 15 \\
\hline Total & 17.5 & 10.83 & 22.71 & 0.713 & 69 \\
\hline \hline
\end{tabular}

TABLE II: MEAN, Minimum AND MAXIMUM FAMILY ANNUAL INCOME (AFGHANI), STANDARD ERROR (S.E.), RECEIVED PER FAMILY FROM

\begin{tabular}{|c|c|c|c|c|c|}
\hline Provinces & בMean & בMin & 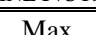 & SEE & $\mathrm{No}$ \\
\hline Paktia & 483.45 & 225 & 1750 & 46.04 & 35 \\
\hline Paktika & 1119.64 & 243.75 & 2862.5 & 175.86 & 19 \\
\hline Khost & 1293.39 & 268.75 & 2812.5 & 202.05 & 15 \\
\hline Total & 965.49 & 245.83 & 2475 & 141.32 & 69 \\
\hline
\end{tabular}

Based on the surveyed findings, families receive an average 965.49 USD per year from sale of pine nuts (Table II). The yearly income from chilgoza pine nuts varies between provinces and from year to year. The Lower family annual income 225 USD was reported in Paktia Province, while the higher 2862.5 USD was reported in Paktika province (Table II). This data was not analyzed in relation to the total weight or number of pine nuts sold; as such, the reported differences in annual income generation per family are at least partially related to the size of the community's forest (number of pine trees), forestry share or distribution part, biennial bearing habit, as well as many other factors. For instance, in Paktika chilgoza forests distribution, the individual family ownership is more apparent, for the reason their annual income is greater than other provinces. The revenue generated from pine nuts divide among village or community members based on the forest distribution. Communities or villages divide the revenue based on the old system of distribution (tribal forms system). According to the surveyed reports, there are conflicts amongst tribes/ communities on forest access and ownership issue and between community members on pine nut revenue distribution. In the case of conflict, tribal shuras or tribal leaders are most commonly responsible to resolve the conflict. In most of the chilgoza pine region, conflicts are resolved in association of tribal shuras and government authorities. Similar findings were also observed by Kuhn et al. [11] and Shalizi and Khuram [16].

\section{F. Production Analysis}

Due to the illegal trading and procuring in forest area, there is no record of exact known volumes of pine nuts produced in Paktia, Paktika and Khost provinces. Based on our study findings and reports from traders, ACCI and DAIL offices of each province, roughly 20,000-27,000 metric tons of chilgoza produce annually in the mentioned provinces (Table III). We did not perform a comprehensive survey as the access to all areas was restricted due to security concerns.

Afghanistan's total pine nut production is $27,000-35,000$ metric tons a year. Of the total production area covered by chilgoza pine nuts in the country, Paktia, Paktika and Khost cover $86 \%$ (37,685 hectare), known as a rich region of Chilgoza pine nut. It's estimated by studies that roughly (120600) families in the mentioned provinces take directly benefits from chilgoza products and the estimated annual revenue in these provinces are 250-360 million dollars [5]. Based on study report of Shalizi and Khuram [16], there were minimum of 320 and maximum of 640 trees/ha in southeast region and according to the finding of [20], an average an adult chilgoza pine tree can yield $7.4 \mathrm{~kg}$ unshelled pine nuts. If we take an average of 260 trees/ha and an average yield of ( $7 \mathrm{~kg}$ unshelled pine nuts/tree), one hectare forest will produce (1.82 MT of unshelled pine nuts), and $(37685 \times 1.82=65948$ MT). Considering of chilgoza biennial bearing habit, south east region (Paktia, Paktika and Khost) have the ability to produce 34500 MT of unshelled pine nuts annually.

TABLE III: CHILGOZA PINE NuTS PRODUCTION AND YIELD (MT/YEAR)

\begin{tabular}{ccccc}
\hline \hline \multirow{2}{*}{ Province } & \multicolumn{4}{c}{ Production (MT/Year) } \\
\cline { 2 - 5 } & 2018 & 2017 & 2016 & 2015 \\
\hline \hline Paktia & 10600 & 11200 & 10300 & 9700 \\
Paktika & 10200 & 10500 & 7800 & 9100 \\
Khost & 4500 & 5100 & 3100 & 2500 \\
\hline Total & 25300 & 26800 & 21200 & 21300 \\
\hline \hline
\end{tabular}

Source: Yields and harvested value is based upon the recorded volume with ACCI and DAIL offices of each province, excluding the illegally traded volume and reports from traders.

\section{G. Conservation and Other Activities}

Chilgoza Pine forests are governed and handled by tribes/communities living near to the forestry area. Based on the study findings, a treaty has been taken from villagers in this regard which explain:

1) Green tree of any forest species is not allowed to cut or damage, if such crime happened, 15000-30000 Afghani has to be paid as a punishment.

2) No transporting vehicle is allowed to inter to the forest area.

3) Each community hired 3-5 forests protective guard (Arbaki) to protect forest from cutting, grazing etc. They are actually member of forestry area/villagers and pay a specific amount as a salary, they have the privilege to collect or cut dry wood only for their family expenditure. 
This treaty has also been confirmed by local government authority.

There are no performance activities of the provincial DAIL in the mentioned provinces in regarding of safeguarding the pine nut forests and surveillance of quality standards in production, harvest, and storage of pine nuts at community and district levels. Moreover, no government and non-government organizations had so far come to work on Chilgoza entire value chain (Production, Harvest, Processing, Storage, Marketing) as there are countless constrains in several aspects such as cone harvesting and collection techniques, cone drying, seed extraction, processing, packaging facilities, trading, storage, marketing and market value chain in Paktia, Paktika and Khost provinces, thus, long and short term program in regarding of capacity buildings, providing technical tools and equipment's, providing technical staffs etc. in entire value chain aspects are an urgent need in order to sustainably manage this valuable natural resource.

TABLE IV: STRENGTHS, WEAKNESSES, THREATS, AND OPPORTUNITIES EXIST IN THE CURRENT CHILGOZA PINE VALUE CHAIN

\begin{tabular}{|c|c|}
\hline Strengths & Weaknesses \\
\hline $\begin{array}{l}\text { - Availability of huge amount of } \\
\text { chilgoza pine forests in the study } \\
\text { areas } \\
\text { - Chilgoza pine trees are easily } \\
\text { grown spontaneously in the areas } \\
\text { - Chilgoza pine trees produce high } \\
\text { quality kernels in addition to wood } \\
\text { and other by-products } \\
\text { - Chilgoza pine nuts consumed and } \\
\text { marketed nationally and } \\
\text { internationally (China) } \\
\text { - Convenience in postharvest } \\
\text { operations except cone collection } \\
\text { - Long term storability and shelf life } \\
\text { - Presence of high market demand } \\
\text { for chilgoza pine nuts even } \\
\text { contracting while they are on the } \\
\text { tree } \\
\text { - Availability of tribal support to } \\
\text { protect forestry areas } \\
\text { Implementation of tribal } \\
\text { preventions on utilizing chilgoza } \\
\text { forests }\end{array}$ & $\begin{array}{l}\text { - Sexual propagation } \\
\text { - Lack of cultivars } \\
\text { - Longer juvenility phase } \\
\text { - Lack of irrigation, fertilization } \\
\text { and other cultural practices } \\
\text { - Illiterateness of the growers to } \\
\text { apply improved practices } \\
\text { - Low survivability of seedlings } \\
\text { obtained from nurseries } \\
\text { - Low germination ability of seed } \\
\text { in nursery } \\
\text { - Slow growth of saplings } \\
\text { - Overgrazing of animals } \\
\text { - Poverty of rural communities and } \\
\text { their reliance mainly on forestry } \\
\text { - Lack of awareness from chilgoza } \\
\text { pine nut value } \\
\text { - High initial costs and longtime } \\
\text { wait until arriving productive } \\
\text { - stage } \\
\text { - Lack of governmental support } \\
\text { either in financial or material } \\
\text { - terms } \\
\text { - Yower regeneration rate of the } \\
\text { species }\end{array}$ \\
\hline Opp & Threats \\
\hline $\begin{array}{ll}\text { - } & \text { Export to Pakistan, India, China } \\
\text { and Central Asian markets } \\
\text { - } \\
\text { Day-to-day increasing demand } \\
\text { in national in international } \\
\text { markets } \\
\text { - } & \text { Boost of the country traders } \\
\text { - } & \text { Employment opportunities } \\
\text { - } & \text { Cooperative marketing and } \\
\text { - } & \text { price stability } \\
\text { Relative governmental support }\end{array}$ & 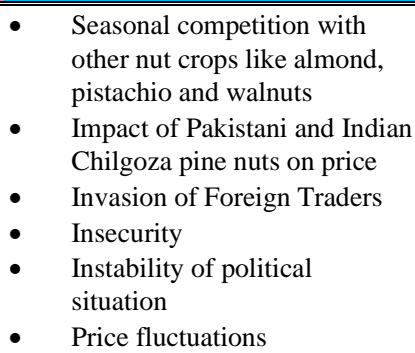 \\
\hline
\end{tabular}

\section{H. SWOT Analysis}

The results of this study showed some internal strengths, weaknesses and external opportunities and threats. The main strengths as shown in the Table IV are accumulation of chilgoza pine forests mainly in the study area, presence of tribal preventions to protect chilgoza forests, on the other hand, low natural regeneration, less attempts for intentional regeneration of the pine forests, low bargaining power of the growers comprise the main weakness. The most considerable opportunity for chilgoza pine growers is the high marketing demands particularly receiving from the Chinese market. The invasion of the foreign traders especially from Pakistan, instability of the country political situation, fluctuations in the monetary exchange rates and seasonal synchrony with other nut crops, are the main factors that threaten the chilgoza pine value chain. The SWOT analysis to be considered in future planning process, presented in Table IV.

\section{CONCLUSION AND RECOMMENDATIONS}

Based on the surveyed results, it can be summarized that chilgoza pine cover in Paktia, Paktika and Khost provinces has significantly reduced due to unsustainable activities. This has resulted in loss of biodiversity and severe land degradation. Chilgoza production is constrained by the over-harvesting of pine cones, unsuitable reforestation practices, lack of information about proper harvesting methods, limited knowledge and skills in modern technologies, improper post-harvest handling and quality control and ineffective marketing skills.

According to the SWOT analysis, the massive population of chilgoza pine trees and presence of tribal support mainly in the study area are the strengths. Likewise, low natural regeneration status, forest unsustainable use, lack of modern harvesting and processing technologies and lower bargaining and marketing skills of the growers comprise the main weakness. A higher marketing demand is a considerable opportunity on the other hand; unstable political situations and monetary exchange rate, invasion of foreign traders and seasonal synchrony with other nut crop are the main threats which should be consider in the future strategic planning process. For better handling of chilgoza pine nut forest; standardizing of entire value chain practices and forest regeneration program will be effective. Appropriate training and capacity buildings in the aspects of sustainable forest use, proper time of harvesting, mature cones identification, proper methods of harvesting, nut processing, raising awareness of international quality and food safety standards may be effective and vital to be conducted. Raising awareness through different sources (media, newspaper, radio etc.) and capacity building in regarding of sustainable forest use may be productive. Establishing modern processing centers and upgrading existing one is an urgent need.

\section{ACKNOWLEDGMENT}

Authors are thankful to the Deutsche Gesellschaft fur Internationale Zusammenarbeit (GIZ, SEDEP) and Paktia University for providing financial support and the necessary facilities to conduct this trial. 


\section{REFERENCES}

[1] A. Farjon, "Pines: drawings and descriptions of the genus Pinus". Leiden: EJ Brill, 1984.

[2] A.R. Malik, G.S. Shamet, J.S. Butola, G.M. Bhat, A.A. Mir, and G. Nabi, "Standardization of seed storage conditions in chilgoza pine (Pinus gerardiana Wall.): an endangered pine of Hind Kush Himalaya", Trees, vol. 27, pp. 1497-1501, 2013.

[3] Anonymous, "Afghanistan National Export Strategy (NEC)", Dried fruits and nuts sector 2018-2022.

[4] Anonymous, "Chilgoza Pine Forest Conservation and Restoration Plan - Draft Report", Ministry of Agriculture, Irrigation and Livestock, Afghanistan, 2012.

[5] Anonymous, "Seeds, fruits and cones". In Non-Wood Forest Products from Conifers; Food and Agriculture Organization (FAO): Rome, Italy, 1995.

[6] Anonymous, 2018a. https://www.dawn.com/news/1307026/2017.

[7] Anonymous, 2018b. http://Exporting Afghan Chilgoza to China Kicks off Via Air Corridor.

[8] Anonymous, 2019. https://www.tolonews.com/business/afghaninvestor-invests-5m-\%C2\%A0pine-nuts\% $2 \% \mathrm{~A} 0$ processing-factory.

[9] E. Ryan, K. Galvin, T. O'connor, A. Maguire, and N. O'brien, " Fatty acid profile, tocopherol, squalene and phytosterol content of brazil, pecan, pine, pistachio and cashew nuts. International Journal of Food Science, vol. 57, pp. 219-228, 2006.

[10] G. Kuhn, E. Hayashi, and J.D. Zach Lea, "Eastern region dried fruits \& nuts subsector / market assessment", Roots of Peace for Development Alternatives, Inc., 2006, available at: http://afghanag.ucdavis.edu/other/topic/markets/marketing/reports/Re p_Market_Asess_East_Reg_Dried_Fruits_Nuts_ROP.pdf.

[11] M. Alam and Lausanne M.B., "Trees and shrubs of Afghanistan: a dendrological guide", Musée botanique, p.333, 2011.

[12] M. Khan, and R. Khan, "Woody Plant Seed Manual - Pakistan)", 1992, available at: http://pdf.usaid.gov/pdf_docs/PNABW321.pdf.

[13] M. Said, "Pinus gerardiana (Chilgoza) in the Zhob District (Quetta/Kalat Circle)". Pakistan Journal of Forestry, vol., pp. 118$123,1959$.

[14] M.N. Shalizi, and S. Khurram, "Traditional and alternative techniques of Chilgoza Pine (Pinus gerardiana Wall.ex D. Don) nut harvesting and processing in Afghanistan", International Journal of Bioassays, vol.5, pp. 5011-5015, 2016.

[15] N.S. Thakur, S. Sharma, and K.D. Sharma, "Standardization of pretreatments for chilgoza (Pinus gerardiana) nut drying", Journal of Food Science and Technology (Mysore), vol. 6, pp.142-145, 2009.

[16] N.S. Thakur, S. Sharma, R. Gupta, and A. Gupta, "Studies on drying and storage of chilgoza (Pinus gerardiana) nuts", Journal of Food Science and Technology, vol. 51, pp. 2092-2098, 2014.

[17] P. Anandajayasekeram, and B. Gebremedhin. "Integrating innovation systems perspective and value chain analysis in agricultural research for development: implications and challenges. Improving Productivity and Market Success (IPMS) of Ethiopian farmers project working paper 16". International Livestock Research Institute, Nairobi, Kenya. 2009.

[18] R. Kaplinsky, and M. Morris, "Globalization and Unequalization: What can be learned from Value Chain Analysis", Journal of Development Studies, vol. 37, pp. 117-146, 2000.

[19] R. Peltier, and V. Dauffy, "The Chilgoza of Kinnaur. Influence of the Pinus gerardiana edible seed market chain organization on forest regeneration in the Indian Himalayas", Fruits, vol. 64, pp. 99-110, 2009 .
[20] R. Urooj, and A. Jabeen, "Present status of Pinus gerardiana Wall. in Pakistan: A review", Middle East Journal of Business, vol. 10, pp., 2015.

[21] S. Kumar, and I.A. Hamal, "Wild edibles of Kishtwar high altitude national park in northwest Himalaya, Jammu and Kashmir (India)", Ethnobotanical Leaflets, vol.1, pp. 23, 2009.

[22] S.G. Harrison, "Edible pine kernels", Kew Bulletin, Vol. 3, pp. 371375, 1951.

[23] S.L. Krugman, and J.L. Jenkinson, "Pinus L. pine. In Seeds of Woody Plants in the United States, Agricultural Handbook", Washington, D.C., USAID, pp. 598-638, 1974.

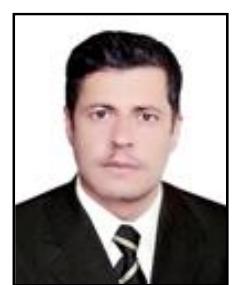

Hedayatullah Salari is currently working as associate professor, horticulture department, agriculture faculty, Paktia University. He has been working there for more than 14 years. He was born in 1984 in Afghanistan. He earned his BSc in General Horticulture from Kabul University in 2007 and MSc in Pomology from Isfahan University of Technology (IUT) in 2013, Isfahan, Iran. He has worked with AHNDO (Afghan National Horticulture Development Organization) as research program officer and data analyst. He analyzed more than 25 research projects replicated each one for 3 years. He guided and accomplished about 10 research projects. He has about 15 published papers (in national and international journals).

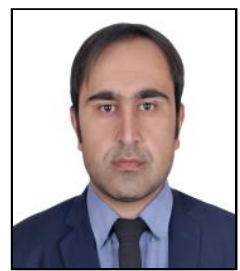

Noorullah Rahmani presently serves as an assistant professor and head of Horticulture department, Agriculture faculty, Pakita University He completed his B.sc (Horticulture) from Kabul University with distinction in 2011. He started his career as Assistant Professor at Paktia University during 2012. In 2013 he qualified to a six months research and training program to IARI, New Delhi, India. Thereafter, he passed a competitive exam and got scholarship to India and successfully completed his Master degree in (Pomology) with first class (A-grade) during 2015- 2017. Mr. Rahmani has worked with different national and international organization. He was employed as a national consultant with GIZ, SEDEP and as a Master trainer and national consultant with DAI/AVC-HVC. Mr. Rahmani has been working on reviving Afghan Chilgoza Pine nut, value chain analysis of chilgoza pine nut and major horticultural crops. He published (9) research articles in national and international journals, (8) subjects chapters and have some un-publicized publications.

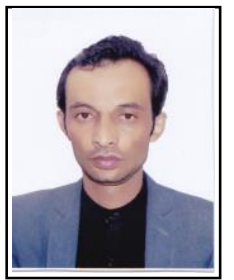

Assistant Professor Abdul Rashid Wiar is currently working with Paktia University, at Forest \& Natura resource Department. He completed his B.Sc. degree with higher marks from Paktia University, Forest and Natural resource Department during 2012 and his master degree from FRI (Forest research Institute Deemed University) at the division of Environment management during 2018. He started his carrier soon after his graduation from Paktia University as a teaching Assistant at and has been working as Head, lecturer and researcher at Forest \& Natural resource department, Paktia University. 